\title{
Gasification of ash-free coal prepared with microwave method
}

\author{
Choong-Gon Lee ${ }^{\dagger}$, Won-Ki Kim, and Duc-Luong Vu \\ Department of Chemical Engineering, Hanbat National University, 125, Dongseodaero, Yuseong-gu, Daejeon 305-719, Korea \\ (Received 25 July $2014 \cdot$ accepted 8 December 2014)
}

\begin{abstract}
The production of ash-free coal as a clean fuel for high temperature fuel cell was investigated. The ash-free coal was made from a bituminous coal. It was prepared by solvent extraction using a microwave. The solvent-to-coal ratio and microwave irradiation time of raw coal were parameters for the extraction yield. The microwave method showed merits in terms of faster extraction and higher extraction yield than conventional heating methods. In addition, gasification behaviors of the ash-free coal were investigated by gas chromatography. Contrary to carbon, ash-free coal showed hydrogen as a dominant gas species in its gasification and did not require carbonate catalyst. The electrical conductivity of ash-free coal was found very low close to zero.
\end{abstract}

Keywords: Ash-free Coal, Solvent Extraction, Microwave, Molten Carbonate, Gasification

\section{INTRODUCTION}

Most fuel cells run with hydrogen fuel. In particular, molten carbonate fuel cells (MCFCs) and solid oxide fuel cells (SOFCs) have high operating temperatures, which allows reforming of methane inside the stack. Consequently, these systems are known as natural gas-based power systems. Generally, natural gas is not an economic energy source because of limited production and high cost for using. But it has very clean characteristics than other liquid and solid fuels. The high cost of natural gas is a hurdle for fuel cell commercialization. On this basis, recent focus has been on the direct carbon fuel cell (DCFC) as a power source.

Coal is a relatively abundant and economic energy source. However, a solid fuel has limited application because of difficulties in the transportation and ash treatment. For the clean use of coal, two processes for the ash-free coal (AFC) are under development: removing ash from the coal by acid or base treatment [1], and extracting organic compounds from the coal [2].

There are four steps in an AFC production by extraction: (1) mixing of coal with solvent to make slurry, (2) heating the slurry to extract organic materials from the coal, (3) separation of solid and liquid, and (4) solidification of the liquid to make AFC. Okuyama et al. reported that AFC is an economic source of energy regardless of these multi-process preparations, because it has a high calorific value and does not require ash treatment [3].

At the early stage, AFC was produced at room temperature. lino et al. reported that they had ca. $60 \%$ of extraction yield (daf, dryash-free base) from a bituminous coal with a 1:1 ratio of N-methyl2-pyrrolidinone (NMP) [4]. However, most cases reported that room temperature gave very low extraction yields [2]. Renganathan et al. reported that they had ca. $60 \%$ of extraction yield with NMP at the boiling point of $202^{\circ} \mathrm{C}$ [5]. It was also reported that quinoline

\footnotetext{
${ }^{\dagger}$ To whom correspondence should be addressed.

E-mail: leecg@hanbat.ac.kr

Copyright by The Korean Institute of Chemical Engineers.
}

at $1 \mathrm{MPa}$ and $350^{\circ} \mathrm{C}$ allowed ca. $80 \%$ of extraction yield [6]. Miura et al. used tetralin as an aprotic solvent and they had $65-80 \mathrm{wt} \%$ of extraction yield (daf) with their own continuous extraction equipment at $350^{\circ} \mathrm{C}$ [7]. Li et al. compared two different polarity solvents, 1-Methylnaphthalene (1-MN) as an aprotic solvent and NMP as a polar one, by continuous extraction for $1 \mathrm{hr}$ at $1 \mathrm{MPa}$ and $360^{\circ} \mathrm{C}$, and they concluded that NMP had ca. 30-40\% higher extraction yields than 1-MN [8]. Zhang et al. also compared solvent effect by using aprotic 1-MN and a mixture of 1-MN and protic indole (20 wt\%) at $360^{\circ} \mathrm{C}$ and $1 \mathrm{MPa}$ [9]. They concluded that the mixture solvent had higher extraction yield by ca. $15 \%$ than 1-MN. Yoshiie et al. used 1-MN as a solvent and two different solvent-to-coal ratios at $360^{\circ} \mathrm{C}[10]$. They reported that a high solvent-to-coal ratio resulted in higher extraction yield. Li et al. also reported that acid pretreatment of coal with methoxyethoxy acetic acid (MEAA) raised extraction yield because acid removes metal ions of $\mathrm{Mg}^{2+}$ and $\mathrm{Ca}^{2+}$ and it relaxes cation cross linking in the coal [8].

Recently, Somnez et al. reported that microwave irradiation (MI) could be an effective heating method for the AFC production [11]. They used the polar solvents NMP and ethylenediamine (EDA) and the non-polar solvent tetralin. It was concluded that extraction yields with MI were comparable to those using the conventional heating method. Lei et al. also reported that an ionic liquid, 1-butyl-3-methyl-imidasolium chloride $([\mathrm{Bmim}] \mathrm{Cl})$ is very effective for extracting Chinese lignite with the microwave method [12]. They compared lignite and sub-bituminous coals and concluded that the ionic liquid had about four times higher extraction yield for the lignite.

Lee et al. reported that carbon with carbonates was oxidized to carbon monoxide at over $700^{\circ} \mathrm{C}$ and ca. $62 \mathrm{~mol} \%$ of $\mathrm{CO}$ was produced [13]. The carbon chemically reacts with carbonate to produce carbon monoxide (Eq. (1)).

$$
\mathrm{C}+\mathrm{CO}_{3}^{2-}=2 \mathrm{CO}+\mathrm{O}^{2-}
$$

In this case, carbonates behave as a catalyst for the oxidation. It was also reported that carbon gasification with steam produced $\mathrm{H}_{2}$ 
as a dominant species [14].

Coal gasification is very similar to carbon gasification. In general, coal gasification has been carried out over $750^{\circ} \mathrm{C}$ and carbonate has been used for the gasification catalyst. Steam has mostly been employed to produce $\mathrm{H}_{2}$ during coal gasification.

However, the gasification behavior of AFC with molten carbonate has rarely been reported. In this work, AFC for the DCFC was produced from a bituminous coal using the MI method. Solventto-coal ratio and microwave irradiation time were parameters for the extraction yields. In addition, gasification behaviors of AFC were investigated in relation to temperature and AFC to carbonate combination.

\section{EXPERIMENTAL}

Berau bituminous coal was ground to be 70 mesh sizes. A certain ratio of coal powder and NMP was mixed in a rounded flask and placed in a microwave. The coal amounts used were $5 \mathrm{~g}, 10 \mathrm{~g}$ and $20 \mathrm{~g}$, and the solvent amounts were $80 \mathrm{ml}$ and $140 \mathrm{ml}$. The microwave was a commercial one made by LG Co. in Korea with up to $1 \mathrm{~kW}$ output power. The upside of the flask was connected to a water cooling condenser, as shown in Fig. 1 . The microwave reached $202^{\circ} \mathrm{C}$ during $30 \mathrm{~min}$ preheating and the temperature was held for 5,10 , and $30 \mathrm{~min}$.

The microwave-treated slurry was filtered with a glass filter to separate solid and liquid phases. The liquid contained extracted coal and solvent, while the solid was residual coal. The extracted coal was dried in a vacuum oven for $40 \mathrm{hrs}$ at $160^{\circ} \mathrm{C}$ and became AFC. The extraction yield of AFC was determined as follows:

$$
\begin{aligned}
& \text { Extraction yield ( } \mathrm{wt} \% \text {, daf) } \\
& \qquad=\frac{\text { feed coal }(\mathrm{daf})-\text { residue coal }(\mathrm{daf})}{\text { feed coal }(\mathrm{daf})} \times 100
\end{aligned}
$$

Industrial analyses of coal, such as water, volatile material and fixed carbon content, were carried out with a TGA-701 (LECO). Elemental analyses of $\mathrm{C}, \mathrm{H}, \mathrm{O}, \mathrm{N}$ were conducted using an analyzer (Thermo, EA1108). Organic bonds in the coal were analyzed by Fourier transform infrared spectroscopy (FT-IR, Nicolet 6700). Thermo-gravimetric analysis (TGA, MettlerToledo 851) was also

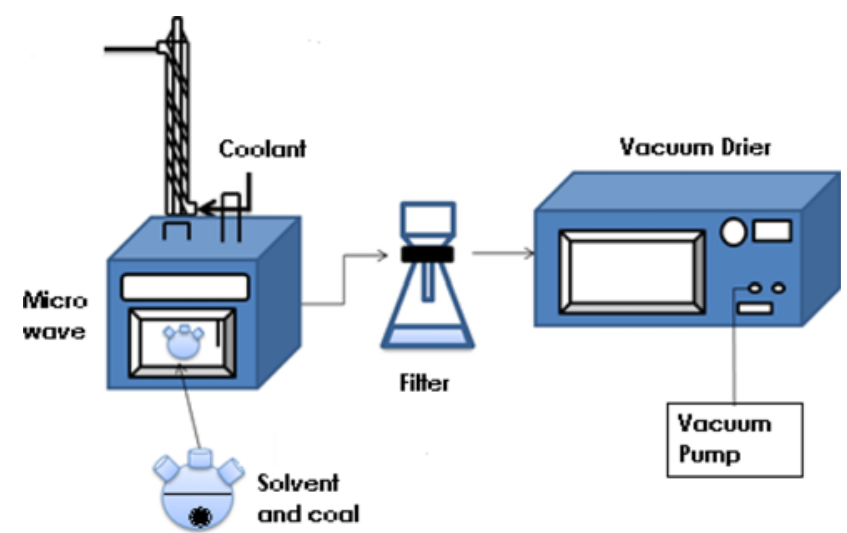

Fig. 1. Atmospheric microwave irradiation system for the solvent extraction from raw coal. used to investigate thermal behavior with $10^{\circ} \mathrm{C} / \mathrm{min}$ rate and $0.1 \mathrm{~L} /$ $\min \mathrm{N}_{2}$ flow. The structure of coal was analyzed with an XRD (Rigaku, D/MAX2500H). The electrical conductivity of AFC was also measured with a resistivity meter (MCP-T370, Mitsubishi Chemical Analytech).

The gases released from AFC with increasing temperature were analyzed by gas chromatography (HP 5890II). The AFC $3 \mathrm{~g}$ only or a mixture of AFC $3 \mathrm{~g}$ and $3 \mathrm{~g}$ of molten carbonates $(62 \mathrm{~mol} \%$ $\mathrm{Li}_{2} \mathrm{CO}_{3}+38 \mathrm{~mol} \% \mathrm{~K}_{2} \mathrm{CO}_{3}$ ) was put in an alumina tube $1.5 \mathrm{~cm}$ in diameter and $10 \mathrm{~cm}$ in length (Fig. 2). Both ends were plugged with $\mathrm{Ni}$ foam to prevent leakage of coal powder, so that gas could come out of the alumina tube. This small alumina tube was inserted in a larger alumina tube ( $3 \mathrm{~cm}$ ID, $25 \mathrm{~cm}$ length and open at one end). The alumina tube was set in a furnace which had a hole to insert the tube. The open end of the tube was plugged with glass wool. A $1.5 \mathrm{~mm}$ diameter alumina tube was installed to sample the gas inside.

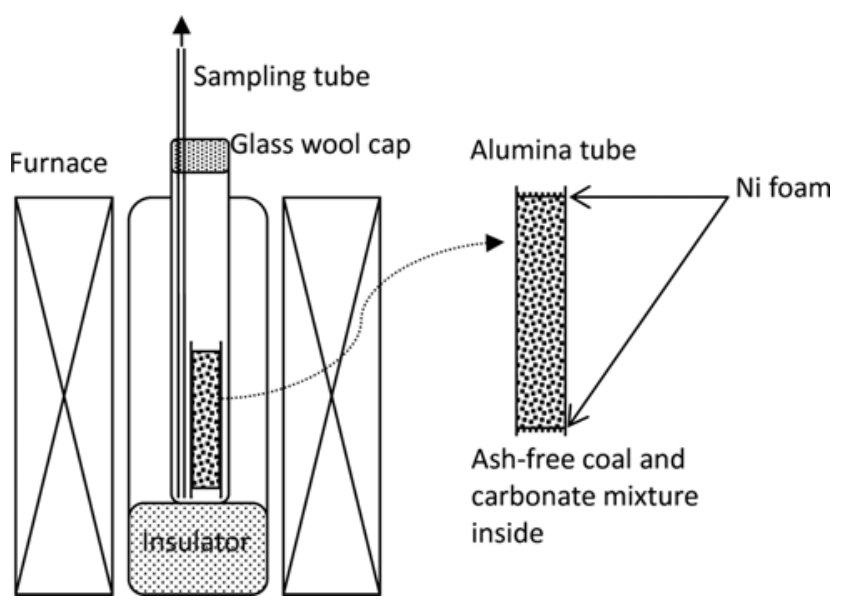

Fig. 2. Gas sampling system from AFC and carbonate mixture.

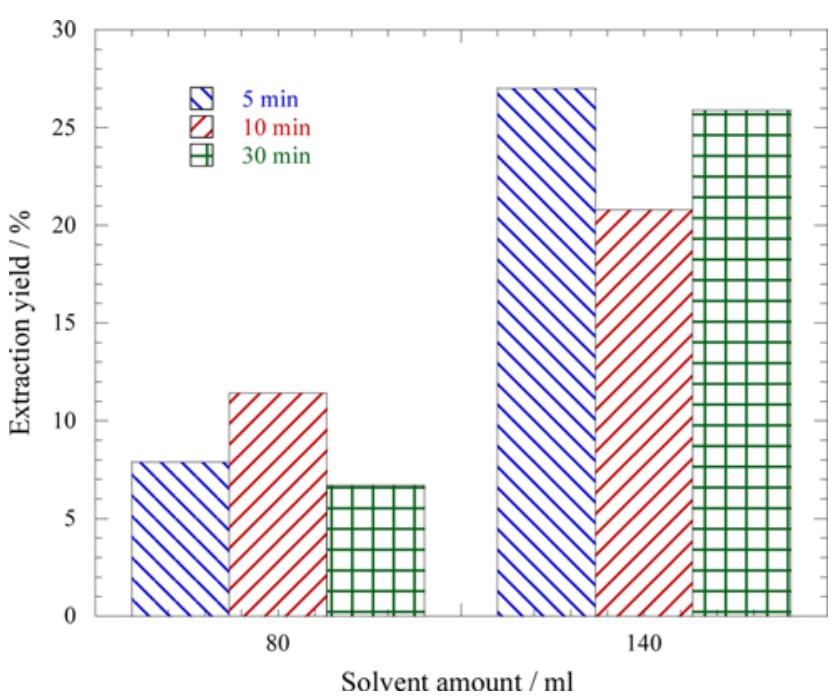

Fig. 3. Comparison of extraction yields in terms of solvent amounts with a fixed $5 \mathrm{~g}$ of raw coal at $202^{\circ} \mathrm{C}$. The bars indicate three times of repeated experiments for 5,10 , and $30 \mathrm{~min}$ holding, respectively. 
Temperature started at $100^{\circ} \mathrm{C}$ and was increased to $900^{\circ} \mathrm{C}$ in $100{ }^{\circ} \mathrm{C}$ increments with $10^{\circ} \mathrm{C} / \mathrm{min}$ rate. At each step a gas sample was collected and analyzed.

\section{RESULTS AND DISCUSSION}

Fig. 3 compares the solvent-to-coal (S/C) ratio with the extraction yields. In this case, $5 \mathrm{~g}$ of coal was used. The results show that high $\mathrm{S} / \mathrm{C}$ ratio definitely gives high yield. About twice the solvent amount results in almost triple the yield. This behavior can be explained by the microwave absorption by the polar solvent. A polar solvent has higher microwave absorbance than a non-polar one [11]. Thus, a larger amount of solvent effectively interacts with coal and extracts organic materials. As shown in Fig. 3, the radiation time cannot be a dominant factor for the extraction. According to Somnez et al. [11], over $10 \mathrm{~min}$ of irradiation results in negligible differences in the extraction yield. In this work, over $5 \mathrm{~min}$ of holding time for irradiation resulted in insignificant differences in the extraction yields. This is acceptable because there is $30 \mathrm{~min}$ of preheating to $202{ }^{\circ} \mathrm{C}$, which is enough time to extract AFC sufficiently.

Fig. 4 shows the effect of coal amount at a fixed solvent amount of $140 \mathrm{ml}$. Increasing the amount of coal reduces the S/C ratio and yields. As mentioned, high yield can be obtained at a high $\mathrm{S} / \mathrm{C}$ ratio. In addition, the effect of holding time is found not to be a domi-

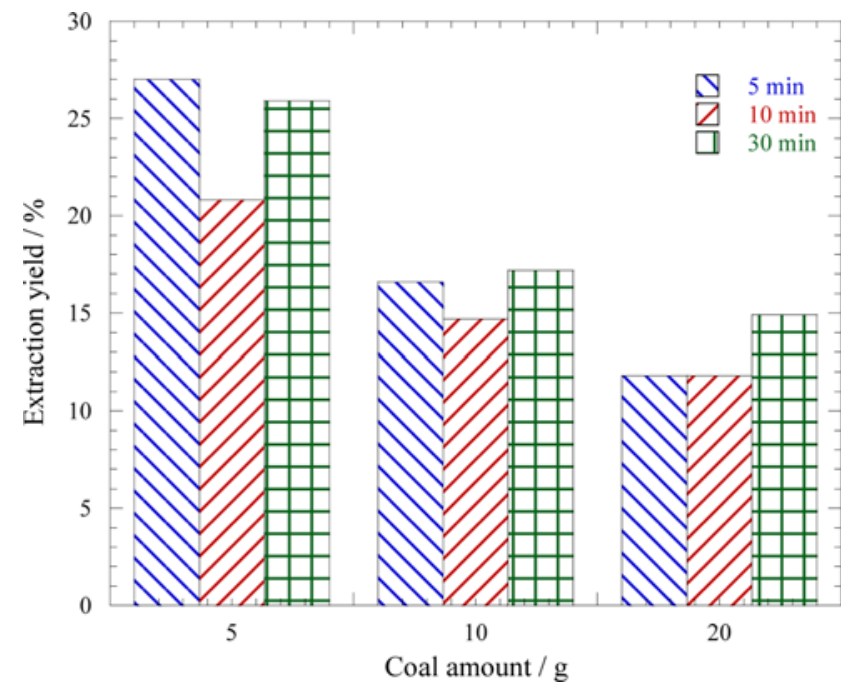

Fig. 4. Comparison of extraction yields in terms of coal amounts with a fixed $140 \mathrm{ml}$ of solvent at $202^{\circ} \mathrm{C}$. The bars indicate three times of repeated experiments for 5,10 , and $30 \mathrm{~min}$ holding, respectively.

Table 1. Proximate analysis of raw coal and AFCs from conventional thermal extraction and microwave irradiation method

\begin{tabular}{lccc}
\hline \hline & Raw coal & $\begin{array}{c}\text { Thermal } \\
\text { extraction }\end{array}$ & $\begin{array}{c}\text { Microwave } \\
\text { irradiation }\end{array}$ \\
\hline Moisture (wt\%) & 15.74 & 2.35 & 2.14 \\
Volatile (wt\%) & 41.06 & 52.74 & 51.34 \\
Ash (wt\%) & 7.78 & 1.61 & 1.37 \\
Fixed carbon (wt\%) & 35.42 & 43.29 & 45.15 \\
\hline
\end{tabular}

nant parameter at the S/C ratios as shown in Fig. 3.

Table 1 compares proximate analysis of the raw coal and AFC with microwave irradiation (MI) and the conventional heat method. The results of the heat method and MI show similarity among the parameters. Water and ash components are drastically decreased in the AFC compared with raw coal. Since the solvent dissolves organic components from the coal and then dried, the AFC has very low amount of ash and water. However, the ash content of AFC with $\mathrm{MI}$ is $1.37 \mathrm{wt} \%$. This is $13,700 \mathrm{ppm}$ of ash, which is a much larger amount than $200 \mathrm{ppm}$ as a general limit for the AFC. The reason is related to the point that a polar solvent has high interaction with coal, so that the polar solvent of NMP has larger ash content (0.51-1.25 wt\%) than non-polar one of 1-MN and LCO (0.02$0.14 \mathrm{wt} \%)$ at the same temperature of $370{ }^{\circ} \mathrm{C}[15,16]$. From a previous work [16], the components of ash in Berau coal are $\mathrm{Fe}_{2} \mathrm{O}_{3}$ (32.7 wt\%), $\mathrm{SiO}_{2}$ (29.7 wt\%), $\mathrm{Al}_{2} \mathrm{O}_{3}$ (19.3 wt\%), $\mathrm{CaO}$ (10.1 wt\%), and other minor species of $\mathrm{MgO}(2.9 \mathrm{wt} \%)$ and $\mathrm{K}_{2} \mathrm{O}(1.6 \mathrm{wt} \%)$.

Table 2 shows the ultimate analysis of raw and AFCs. Components of $\mathrm{N}, \mathrm{H}$, and $\mathrm{O}$ are increased by the MI treatment. Since NMP has N, H, O elements, their increases can be accepted.

Fig. 5 shows XRD data for raw coal and AFC. The raw coal shows very broad peaks, which indicates a typical amorphous structure. Very similar pattern for the AFC also represents its amorphous structure.

Fig. 6 compares TGA behaviors of raw coal and AFC. The steep decrease for the raw coal up to $100^{\circ} \mathrm{C}$ is probably due to water evap-

Table 2. Elemental analysis of raw coal and AFC with microwave method

\begin{tabular}{lcr}
\hline \hline & Raw coal & AFC \\
\hline N (wt\%) & 1.32 & 2.90 \\
C (wt\%) & 72.46 & 72.23 \\
H (wt\%) & 4.08 & 5.24 \\
O (wt\%) & 14.16 & 18.26 \\
Ash (wt\%) & 7.78 & 1.37 \\
\hline
\end{tabular}

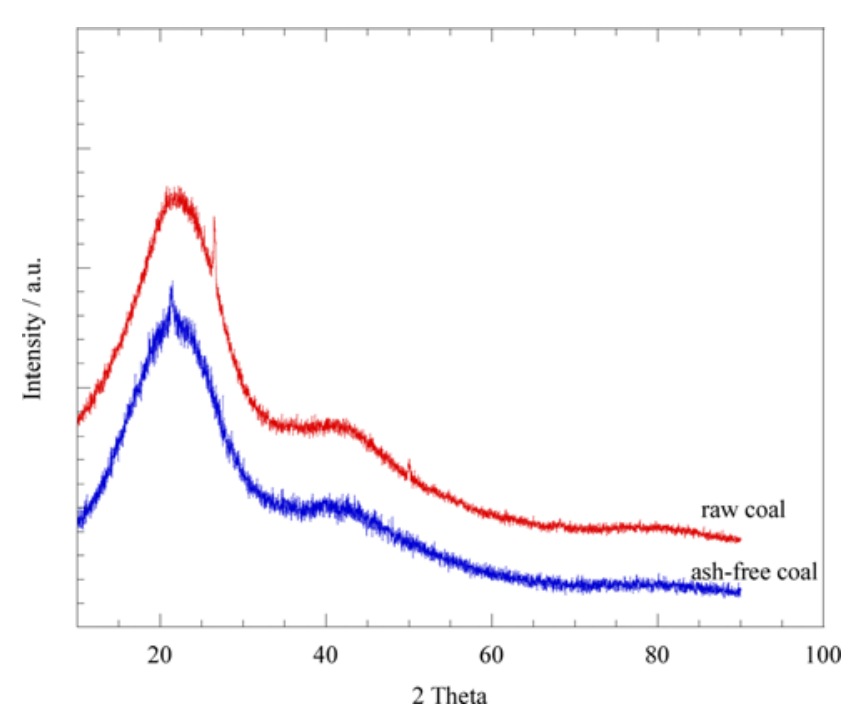

Fig. 5. XRD patterns of raw coal and AFC. 


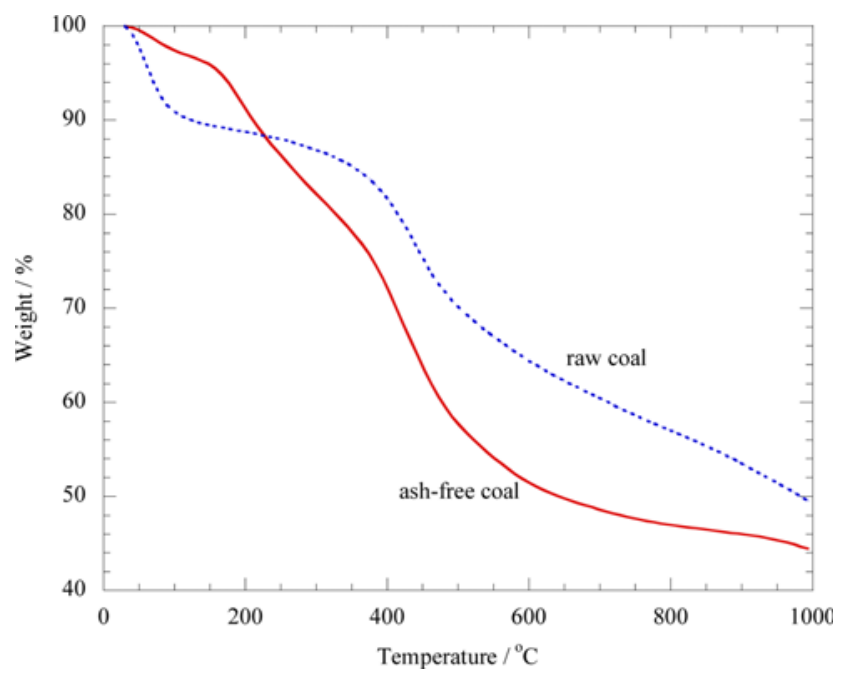

Fig. 6. TGA results of raw coal and AFC with $10^{\circ} \mathrm{C} / \mathrm{min}$ under $0.1 \mathrm{~L} /$ min $\mathrm{N}_{2}$ environment.

oration because the Berau coal was used as received. Then another rapid decomposition is observed over $400{ }^{\circ} \mathrm{C}$ for the raw coal. Organic species should be responsible for this weight loss. On the other hand, the AFC shows a mild decrease up to $190^{\circ} \mathrm{C}$ because it was vacuum dried. The decomposition is responsible for the very volatile materials. Over $200{ }^{\circ} \mathrm{C}$ a steeper decrease in the weight is observed until $400^{\circ} \mathrm{C}$. Then further rapid decomposition is obtained above $400{ }^{\circ} \mathrm{C}$. Finally, the decomposition diminishes and arrives at ca. $45 \%$ at $1,000^{\circ} \mathrm{C}$. The TGA was carried out under $\mathrm{N}_{2}$ condition, and most organic materials decompose above $300^{\circ} \mathrm{C}$, so the remains at $1,000{ }^{\circ} \mathrm{C}$ would be carbon species. Considering ca. $8 \mathrm{wt} \%$ of ash content in the raw coal, the weight difference between the raw coal and AFC at $1,000^{\circ} \mathrm{C}$ can be acceptable. Therefore, about $50 \%$ of organic materials are decomposed up to $1,000^{\circ} \mathrm{C}$.

Fig. 7 shows FT-IR spectra of raw coal with solvent (ml)-to-coal

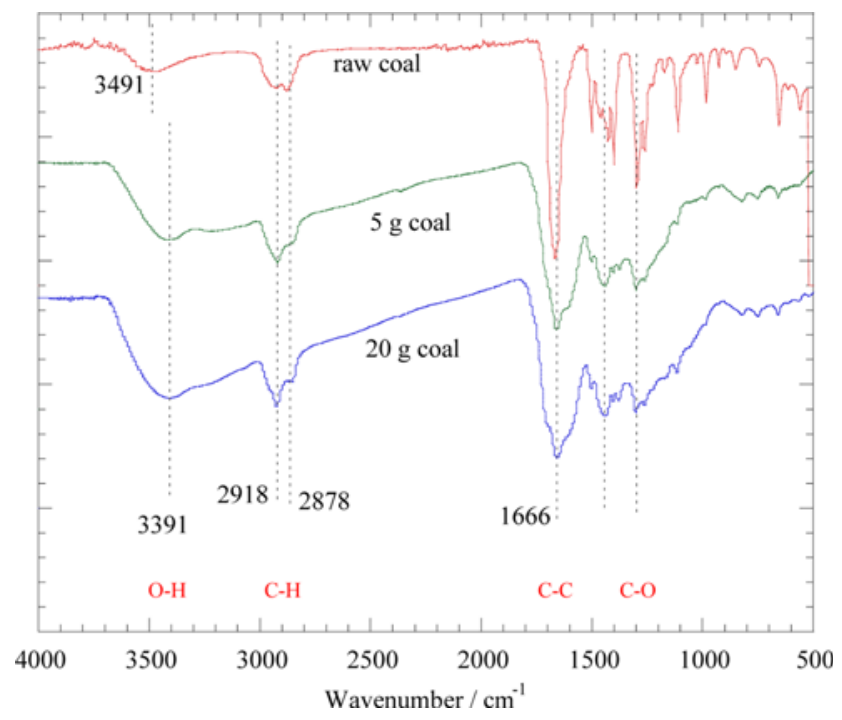

Fig. 7. FTIR patterns of raw coal and AFCs from $5 \mathrm{~g}(\mathrm{~S} / \mathrm{C}=28 / 1)$ and $20 \mathrm{~g}(\mathrm{~S} / \mathrm{C}=7 / 1)$ raw coals to $140 \mathrm{ml}$ solvent. (g) (S/C) ratios of 28/1 and 7/1. As $140 \mathrm{ml}$ of solvent were used in all cases, coal amounts were $5 \mathrm{~g}$ and $20 \mathrm{~g}$, respectively. At $3,492 \mathrm{~cm}^{-1}$, small absorption is observed for the raw coal, while AFC has a much larger peak at $3,391 \mathrm{~cm}^{-1}$. Those two peaks could be attributed to the $\mathrm{O}-\mathrm{H}$ bond. Lei et al. reported that reduction of $\mathrm{O}$ amount in the AFC reduced the peak height of $3,420 \mathrm{~cm}^{-1}$ [12]. The AFC in this work had a larger amount of $\mathrm{O}$ species than the raw coal. Thus, the increased $\mathrm{O}$ amounts in the AFC enlarged the peak height. The two peaks at 2,918 and $2,878 \mathrm{~cm}^{-1}$ are due to $\mathrm{C}-\mathrm{H}$ bonds, and the height ratio between them is reversed in the AFC. The peak at 1,666 $\mathrm{cm}^{-1}$ is mainly due to the $\mathrm{C}=\mathrm{C}$ bond in the aromatic ring, and the peak at $1,300 \mathrm{~cm}^{-1}$ is mostly due to the $\mathrm{C}-\mathrm{O}$ bond. Therefore, the AFC has various chemical bonds among $\mathrm{C}, \mathrm{H}$, and $\mathrm{O}$.

The electrical conductivity of AFC was close to zero and found to be non-conductive material. Since the solvent dissolves the organic species from the coal and then it is dried to be a solid, the AFC becomes an organic solid material and its non-conductivity can be accepted.

For the coal gasification, air or oxygen is introduced to the reactor to maintain the temperature by burning coal. Thus the outlet gas composition is determined by the inlet gas species. An air inlet makes a nitrogen gas mixture for the outlet gas, while oxygen only produces $\mathrm{C}, \mathrm{H}$, and $\mathrm{O}$ mixed compounds.

Molten carbonate based DCFC generally uses carbon and carbonate mixture for the anode fuel. The carbonate behaves as a catalyst for the carbon oxidation to the carbon monoxide. Since the DCFC has difficulty in the gas sealing inside, inert gas is introduced into the anode chamber to increase the gas pressure inside and to prevent oxygen diffusion from outside. In a previous work, humidified nitrogen and air flow produced $\mathrm{H}_{2}$ as a main gas component in the carbon and carbonate mixture at $800{ }^{\circ} \mathrm{C}$ [14]. It indicates that steam reforming of AFC is possible in the DCFC.

To investigate the oxidation process of AFC in a DCFC, we measured gas composition without flowing any gas species into the anode. Fig. 8 shows gas composition changes with only $3 \mathrm{~g}$ of AFC according to the temperature rising. The temperature was increased incrementally up to $900^{\circ} \mathrm{C}$, and at each temperature gas analysis was carried out with three times using a gas chromatography. At $100{ }^{\circ} \mathrm{C}$,

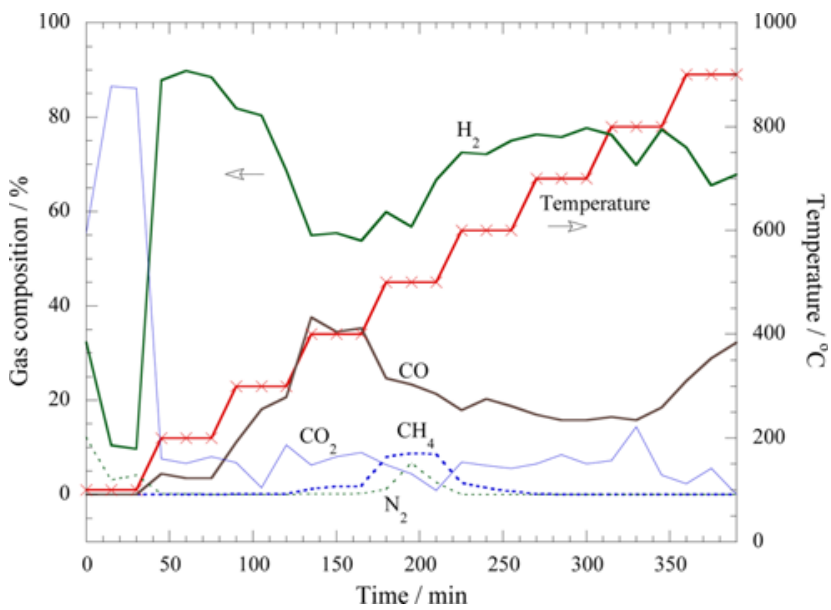

Fig. 8. Gas compositions from only $3 \mathrm{~g}$ of AFC during step like temperature rising from $100{ }^{\circ} \mathrm{C}$ to $900{ }^{\circ} \mathrm{C}$. 


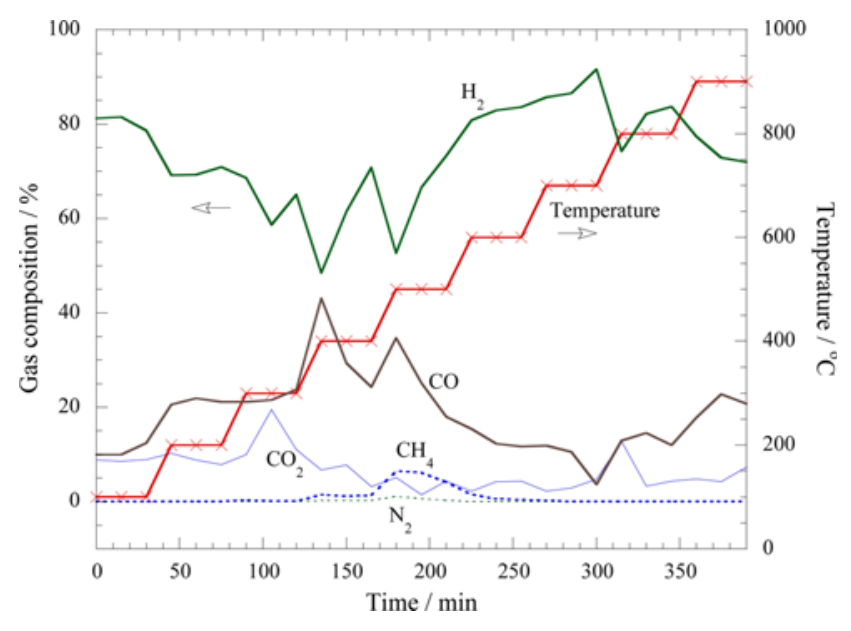

Fig. 9. Gas compositions from $3 \mathrm{~g}$ of $\mathrm{AFC}$ and $3 \mathrm{~g}$ of $\mathrm{Li}-\mathrm{K}$ carbonates during step like temperature rising from $100^{\circ} \mathrm{C}$ to $900^{\circ} \mathrm{C}$.

a significant amount of $\mathrm{CO}_{2}$ was observed at the bottom of the AFC container. In general, carbon cannot be burnt at this temperature. The reason is as yet unclear, but it is plausible that $\mathrm{CO}_{2}$-containing compounds would be decomposed. At $200{ }^{\circ} \mathrm{C}$, over $80 \%$ of $\mathrm{H}_{2}$ was observed. Contrary to the carbon gasification, AFC produces a sufficient amount of $\mathrm{H}_{2}$ even at $200^{\circ} \mathrm{C}$. From $300^{\circ} \mathrm{C}$, $\mathrm{CO}$ generation is observed. It is maximized at $400{ }^{\circ} \mathrm{C}$, and $\mathrm{CO}$ composition is reduced above this temperature. The species of $\mathrm{CH}_{4}$ and $\mathrm{N}_{2}$ are observed at $500{ }^{\circ} \mathrm{C}$, and these components are liberated from the AFC. Above $600^{\circ} \mathrm{C}$, the gas compositions are invariable up to $900^{\circ} \mathrm{C}$.

Fig. 9 shows gas generation of $3 \mathrm{~g}$ AFC and $3 \mathrm{~g}$ of carbonate mixture. At $100^{\circ} \mathrm{C}$, a very large amount of $\mathrm{H}_{2}$ and low amount of $\mathrm{CO}_{2}$ are observed. Except for the behavior, the composition change with temperature is very similar to those of Fig. 8. Even with the molten condition of carbonate over $500{ }^{\circ} \mathrm{C}$, the gas compositions are comparable to those in Fig. 8. The similarity of gas composition with temperature between Figs. 8 and 9 indicates that carbonate may not behave as a catalyst for the gasification of AFC. Unlike carbon, AFC contains various compounds and their gasification progresses without the need for a catalyst.

\section{CONCLUSION}

AFC production from a bituminous coal has been conducted by using a solvent extraction method with a microwave. The microwave irradiation method has very fast extraction time compared with the conventional heating method; ca. $30 \mathrm{~min}$ was sufficient to extract AFC, while the conventional heating method took ca. $24 \mathrm{hrs}$. The AFC yield was significantly dependent on the solvent-to-coal $(\mathrm{S} / \mathrm{C})$ ratio; high S/C ratio gave high yield. The structure of AFC was amorphous and very similar to the original coal according to XRD measurement. The chemical bonding of AFC was very similar to that of the original coal except for a stronger $\mathrm{O}-\mathrm{H}$ bond in the AFC. The gasification of AFC with and without carbonate from $100{ }^{\circ} \mathrm{C}$ up to $900^{\circ} \mathrm{C}$ was very similar; $\mathrm{H}_{2}$ was the dominant gas species for all temperature ranges and $\mathrm{CO}$ was the second largest species. The species of $\mathrm{CO}_{2}, \mathrm{CH}_{4}$ and $\mathrm{N}_{2}$ had minor compositions. The results indicate that the gasification of $\mathrm{AFC}$ did not require a carbonate catalyst.

\section{ACKNOWLEDGEMENT}

This research was supported by Basic Science Research Program through the National Research Foundation of Korea (NRF) funded by the Ministry of Education, Science and Technology (2011-0009748).

\section{REFERENCES}

1. E. Jorhani, H. Ghasemi Chapi and M. Tayebi Khorami, Fuel Process. Technol., 92, 1898 (2011).

2. T. Yoshida, T. Takanohashi, K. Sakanishi, I. Saito, M. Fujita and K. Mashimo, Fuel, 81, 1463 (2002).

3. N. Okuyama, N. Komatsu, T. Shigehisa, T. Kaneko and S. Tsuruya, Fuel Process. Technol., 85, 947 (2004).

4. M. Iino, T. Takanohashi, H. Ohsuga and K. Toda, Fuel, 67, 1639 (1988).

5. K. Renganathan, J. W. Zondlo, E. A. Mintz, P. Kneisl and A. H. Stiller, Fuel Process. Technol., 18, 273 (1988).

6. K. Ouchi, S. Itoh, M. Makabe and H. Itoh, Fuel, 68, 735 (1989).

7. K. Miura, M. Shimada and H. Huan, Fuel, 80, 1573 (2001).

8. C. Li, T. Takanohashi, I. Saito, M. Iino, H. Aoki and K. Mashimo, Energy Fuels, 18, 97 (2004).

9. L. Zhang, H. Kawashima, T. Takanohashi, T. Nakazato, I. Saito and H. Tao, Energy Fuels, 22, 1183 (2008).

10. R. Yoshiie, H. Watanabe, S. Uemiya, A. Furuya, N. Okuyama and N. Komatsu, Fuel, 102, 26 (2012).

11. O. Somnez and E. Giray, Fuel, 90, 2125 (2011).

12. Z. Lei, L. Wu, Y. Zhang, H. Shui, Z. Wang, C. Pan, H. Li, S. Ren and S. Kang, Fuel, 95, 630 (2012).

13. C.-G. Lee, H. Hur and M.-B. Song, J. Electrochem. Soc., 158, B410 (2011).

14. A. Sharma, T. Takanohashi, K. Morishita, T. Takarada and I. Saito, Fuel, 87, 491 (2008).

15. K. Masaki, T. Yoshida, C. Li, T. Takanohashi and I. Saito, Energy Fuels, 18, 995 (2004).

16. S.-H. Lee, Development of ashless coal production and application technology (III), KIER-A82801, A report of Korea Institute of Energy Research (2008). 